\begin{tabular}{c|c}
$\begin{array}{c}\text { Bulletin of } \\
\text { SCIENTIFIC CONTRIBUTION } \\
\text { Fakultas Teknik Geologi } \\
\text { UNIVERSITAS PADJADJARAN }\end{array}$ & $\begin{array}{c}\text { p-ISSN : 1693 - 4873 } \\
\text { e-ISSN : 2541 - 514x } \\
\text { Volume 14, No.3 } \\
\text { Desember 2016 }\end{array}$ \\
\hline
\end{tabular}

\title{
HOST ROCK AND MINERALIZED ORES GEOCHEMISTRY OF BANTARHUNI VEIN, ARINEM DEPOSIT, WEST JAVA - INDONESIA
}

\author{
Euis Tintin Yuningsih \\ Faculty of Geology - Padjadjaran University
}

\begin{abstract}
There are closed spatial relationship between the different phases, the different metallic minerals, the precious-metals bearing minerals, the volcanic host rock and the plutonic intrusions of the Arinem vein system. Nine samples from Bantarhuni vein including four samples from quartz-sulfide vein from different stages and level, and five samples from altered host rock were analyzed geochemically by Induced Couple Plasma (ICP) and Induced Couple Plasma Mass Spectrometer (ICP-MS) to identified the geochemical characteristics of Bantarhuni vein system. The geochemical data obtained from the quartzsulfide vein and altered host rock of the Bantarhuni vein is mostly similar to those obtained from Arinem vein samples. Some samples from the alteration zone have contents similar to the less altered Jampang Formation and andesitic Miocene and Pliocene intrusions rocks, with a little depletion and enrichment for some oxides. The abundance of ore and gangue minerals vary among each stage of mineralization of Bantarhuni vein. The REE in the Arinem and Bantarhuni veins considered to have been extracted by water/rock interaction between hydrothermal solution and country rocks. Some REE pattern of the mineralized Bantarhuni vein show irregularly pattern and this is could be due to high content of sulfide minerals in the samples, or due to analytical error during sample dissolution. The gold and silver contents in the Arinem and Bantarhuni veins vary very much and there is relatively low $\mathrm{Au}$ and $\mathrm{Ag}$ concentrations occur in samples from any alteration zone. There is no correlation found between gold and other major ore elements except for Ag. The highest content of Au is having low $\Sigma$ REE.
\end{abstract}

Keywords : Bantarhuni vein, Geochemical, quartz-sulfide vein, water-rock interaction.

\begin{abstract}
ABSTRAK
Terdapat hubungan spasial antara fase yang berbeda, mineral logam yang berbeda, mineral yang mengandung logam mulia, batuan induk (host rock) vulkanik dan intrusi plutonik dalam sistem urat Arinem. Sembilan sampel dari urat Bantarhuni yang terdiri dari empat sampel dari urat kuarsa-sulfida dari stages dan kedalaman yang berbeda, dan lima sampel dari host rock yang terubah dianalisis secara geokimia degan Induced Couple Plasma (ICP) dan Induced Couple Plasma Mass Spectrometer (ICP-MS) untuk mengidentifikasi karakteristik geokimia dari sistem urat Bantarhuni. Data analisis geokimia yang diperoleh dari urat kuarsa-sulfida dan batuan induk terubah dari urat Bantarhuni sebagian besar sama dengan yang diperoleh dari sampel urat Arinem. Beberapa sampel dari zona alterasi memiliki kandungan mirip dengan Formasi Jampang yang terubah lemah dan batuan intrusi andesit berumur Miosen dan Pliosen, dicirikan dengan sedikit pengurangan dan pengayaan untuk beberapa oksida. Kelimpahan bijih dan mineral gang bervariasi di dalam setiap tahap mineralisasi di urat Bantarhuni. REE di urat Arinem dan Bantarhuni kemungkinan diekstraksi dengan adanya interaksi air/batuan antara fluida hidrothermal dan batuan sampingnya. Beberapa pola REE dari urat Bantarhuni yang termineralisasi menunjukkan pola yang tidak teratur dan hal ini kemungkinan disebabkan oleh tingginya kandungan mineral sulfida dalam sampel, atau karena kesalahan pada saat analisis dalam pelarutan sampel. Kandungan emas dan perak dalam urat Arinem dan Bantarhuni sangat bervariasi dan konsentrasi Au dan Ag pada sampel dari setiap zona alterasi relatif rendah. Tidak ada korelasi ditemukan antara emas dan unsur bijih utama lainnya kecuali dengan Ag. Sampel dengan kandungan Au tertinggi adalah sampel yang memiliki $\Sigma$ REE rendah.
\end{abstract}

Kata kunci : Urat Bantarhuni, geokimia, urat kuarsa-sulfida, interaksi air-batuan.

\section{INTRODUCTION}

Geochemical zoning in epithermal system can be studied on a variety of scales, including regional, district, and ore body or ore-shoot dimensions. Ideally, patterns of geochemical zoning, once they are established, should be usable guides to location of additional ore bodies. Most models of epithermal deposits suggest generalized geochemical zoning patterns that presumably may be apply to all epithermal ore deposits. Silberman and Berger (1985) believe that these zoning patterns are specific to individual mineralizing systems, and that a unique, widely applicable model of 
element zoning to delineate ore in all districts will probably not be achieved. There is considerable variation in the pathfinder elements associated with precious-metal mineralization, particularly in their lateral and vertical changes in concentration.

In any particular deposit or district, the geochemical zoning patterns do tend to have regularity, and once established, can serve as guides to additional reserves or sites of mineralization in that district. That is, they have application to prospecting only after their relationships to known mineralization are established.

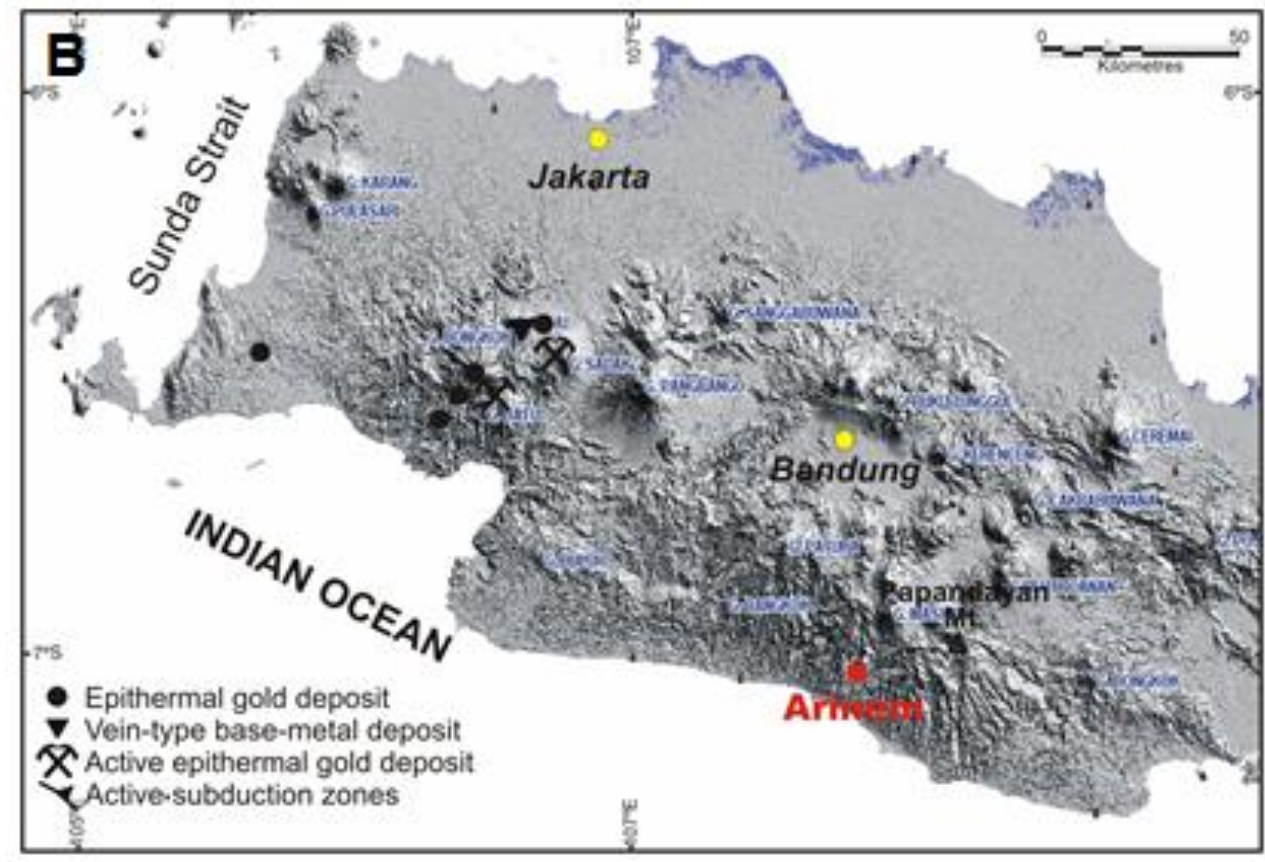

Fig. 1 Morphology of western Java with the distribution of active volcanoes and ore deposits. The location of the Arinem deposit is indicated.

The epithermal Arinem deposit (Fig.1) contains the precious metals $\mathrm{Au}-\mathrm{Ag}$, and the abundant of $\mathrm{Cu}, \mathrm{Pb}$ and $\mathrm{Zn}$ base metals (Yuningsih et al, 2012; Yuningsih and Matsueda, 2014). The mineralization mainly occurs in quartzsulfide vein within the host volcanic rocks which belong to the Jampang Formation and show different degrees of alteration. Differences in alteration can be recognized in the field from the centre of the ore deposits to the margin of the mineralized area. There are closed spatial relationship between the different phases, the different metallic minerals, the precious-metals bearing minerals, the volcanic host rock and the plutonic intrusions of the Arinem vein system. The mineralization occurs in the quartz-sulfide vein and rare in altered host rock. In some respect the mineralization is bounded by weak zones in the tension-fault area.

\section{METHODOLOGY}

Some samples taken from mineralized quartz-sulfide vein and altered host rock of the Bantarhuni vein were prepared for analyses. The elements presented are major, minor, trace and rare earth elements from all the analyzed samples to get detail geochemical features of the mineralized vein body and host rock. Nine samples from Bantarhuni vein were analyzed for REE including four samples from quartz-sulfide vein from different stages and level, and five samples from altered host rock.

All samples were clarified by petrographic study, some samples from quartz-sulfide vein were clarified by EPMA, and altered host rock samples by XRD measurement. The geochemical analysis for mineralized vein body, altered host rock and intrusion were carried out at the Acme Analytical Laboratories (Vancouver) Ltd. British 
Columbia, Canada. The determination had done by Induced Couple Plasma (ICP) and Induced Couple Plasma Mass Spectrometer (ICP-MS) emission spectrometry to extend the lower detection limits and provide a broader spectrum of elements.

\section{RESULTS AND DISCUSSIONS Major Element Geochemistry of Bantarhuni Vein}

The geochemical data obtained from the quartz-sulfide vein and altered host rock of the Bantarhuni vein is mostly similar to those obtained from Arinem vein samples. The result of geochemical analysis for major element from Bantarhuni vein of the mineralized vein and altered host rock samples are summarized in Table 1 as comparison for geochemical analysis of Arinem. The content of $\mathrm{SiO}_{2}$ in quartz-sulfide vein is in the wide range between 8.6 to $65.9 \%$, and in altered host rock is between 49.4 to $77.5 \%$. The $\mathrm{K}_{2} \mathrm{O}$ and $\mathrm{Al}_{2} \mathrm{O}_{3}$ content in altered host rock slightly and strongly higher than quartzsulfide vein, $\mathrm{Fe}_{2} \mathrm{O}_{3}$ in quartz-sulfide vein variable but higher. The $\mathrm{Na}_{2} \mathrm{O}, \mathrm{TiO}_{2}$ and $\mathrm{P}_{2} \mathrm{O}_{5}$ content are varies but slightly lower in the mineralized quartz-sulfide vein.

Altered propylitic and argillic show similar major element content. Some samples from the alteration zone have contents similar to the less altered Jampang Formation and andesitic Miocene and Pliocene intrusions rocks, with a little depletion and enrichment for some oxides. The content of $\mathrm{Na}_{2} \mathrm{O}$ is depleted, $\mathrm{K}_{2} \mathrm{O}$ is enriched and $\mathrm{SiO}_{2}$ is variable comparing to less altered Jampang Formation outcrop. Sample from mineralized vein of $\mathrm{BBH} 10-51$ show high content of $\mathrm{CaO}(33.2 \%)$ as a result of the calcite association in the sample. The high content of $\mathrm{Fe}_{2} \mathrm{O}_{3}$ in mineralized samples of stage II comparing to stage I is resulted from the higher content of pyrite (and chalcopyrite) in the stage II.

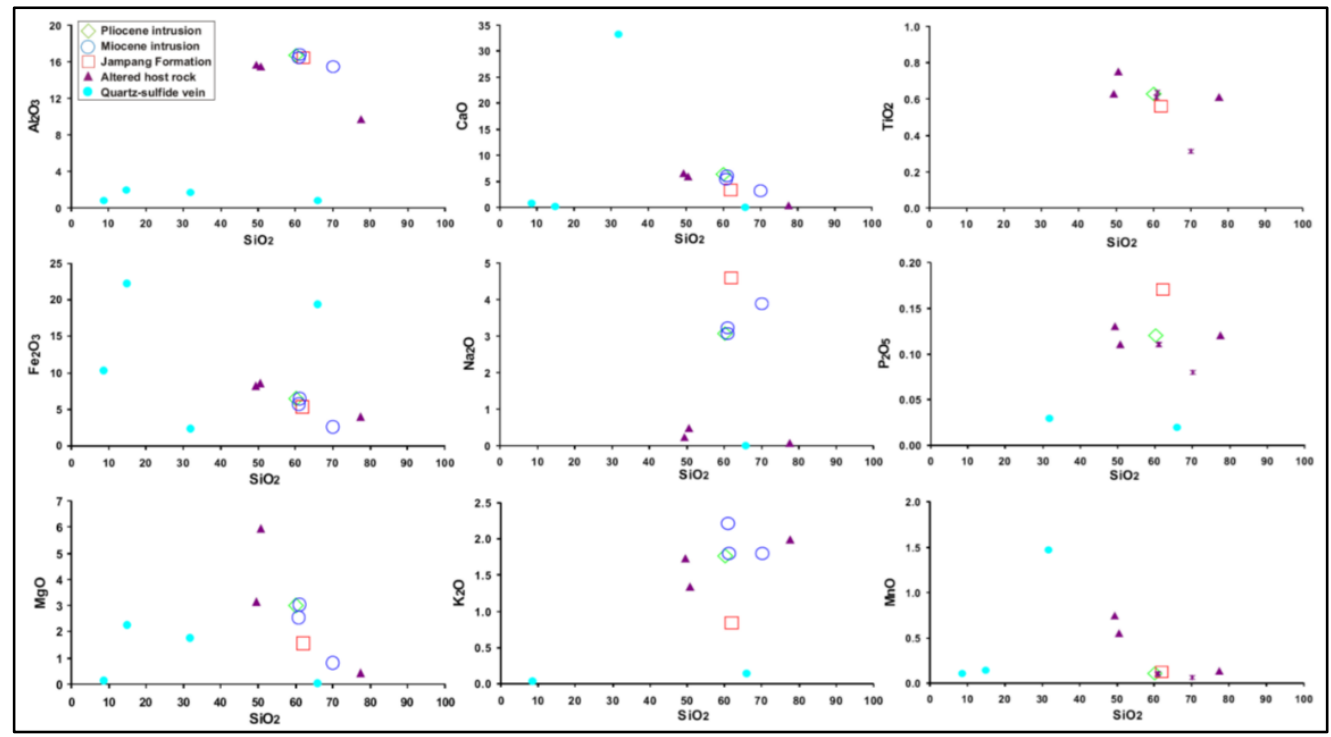

Fig. 2 The relation between the $\mathrm{SiO}_{2}$ and the major elements content in quartzsulfide vein and altered host rock of Bantarhuni vein samples with comparison with less altered Jampang Formation and fresh Miocene-Pliocene intrusions of outcrop samples

observed for various oxides against

The major element of the mineralized vein and altered host rock data of the Bantarhuni vein is plotted on the Harker diagram (i.e. $\mathrm{SiO}_{2}$ versus major oxides, Fig. 2). It is clear from this diagram that no well-defined trend has been
$\mathrm{SiO}_{2}$. It is indicating that the fractional crystallization has not played a major role in the formation of these mineralized vein and altered host rock. But this also could be influenced by the samples analyzed limitation and some 
samples analyzed also shows the occurrence of under detection limit value. However, the role of partial melting not be ruled out in this regard. The graphic in Fig. 2 shows the alteration host rock have vaguely defined positive trend against $\mathrm{SiO}_{2}$ for $\mathrm{Al}_{2} \mathrm{O}_{3}$ and $\mathrm{P}_{2} \mathrm{O}_{5}$ with similar composition, $\mathrm{TiO}_{2}$ and $\mathrm{K}_{2} \mathrm{O}$ of altered host rock higher and mineralized vein lower; $\mathrm{Na}_{2} \mathrm{O}$ both altered host rock and mineralized vein are lower; $\mathrm{CaO}, \mathrm{MgO}$ and $\mathrm{MnO}$ show uneven pattern relative to less altered Jampang Formation, Miocene and Pliocene intrusions and this is similar with pattern obtained from the Arinem vein. This is suggesting the fractionation behavior for these rocks are similar.

However, due to the scarcity of the samples from Bantarhuni core samples, no conclusion can be made in this regard. It is clear from the Table 5.3 and the Fig. 2 that the samples mineralized vein is relatively poor in $\mathrm{Al}_{2} \mathrm{O}_{3}$ and $\mathrm{Na}_{2} \mathrm{O}$ and rich in $\mathrm{Fe}_{2} \mathrm{O}_{3}$. Those are due to the presence of sulfide mineral such as pyrite in the samples. $\mathrm{K}_{2} \mathrm{O}$ enrichment is found in all of the altered zones.

The discrimination diagrams based on major elements $\left(\mathrm{SiO}_{2}, \mathrm{Na}_{2} \mathrm{O}, \mathrm{K}_{2} \mathrm{O}\right)$ and mobile elements are sometimes not very effective, when the rocks are subjected to metamorphism and alteration due to tectonism. In these conditions, discrimination diagram based on immobile and compatible elements are proposed to further confirm their tectonic affinity (Winchester \& Floyd, 1977). These diagrams are not only helpful in understanding the tectonic setting but also useful to determine the character of the magma source responsible for formation of rocks and its influent to the mineralized vein.

\section{Minor, Trace and Rare Earth Elements Geochemistry of Bantarhuni Vein}

The large lithophile elements of $\mathrm{Ba}$ and $\mathrm{Rb}$ strongly depleted for the samples from mineralized vein and various but mostly depleted for samples from the altered host rock. The Sc, Cs Hf, Nb, V and $\mathrm{W}$ various but mostly depleted, except for samples of $\mathrm{BBH} 10-51$ (IB) contains $\mathrm{W}$ up to 192.8 and $\mathrm{BBH}$ 5-27.2 (IIB) has Sc up to $39.0 \mathrm{~g} \mathrm{t}^{-1}$. Samples $\mathrm{BBH} 4 \mathrm{~A}-43$ and $\mathrm{BBH}$ 5-28 (IIC) have $\mathrm{Ga}$ up to 25.2 and $15.4 \mathrm{~g} \mathrm{t}^{-1}$, respectively. Other trace elements of mineralized vein and altered host rock are almost similar comparing altered host rock and less altered Jampang Formation, and Miocene and Pliocene intrusions. The Sr, $\mathrm{Zr}$ and $\mathrm{Y}$ for mineralized vein strongly depleted except for samples BBH 10-51 (IB) is up to $88.6 \mathrm{~g} \mathrm{t}^{-1}$, and altered host rock is similar with altered host rock taken from Arinem vein, it is slightly depleted. In opposite, Co content for mineralized vein is depleted and altered host rock is enriched. The content of $\mathrm{V}$ depleted in mineralized vein but enriched in altered host rock.

The Th contents are variable, for the mineralized vein samples they are relatively low $\left(<2 \mathrm{~g} \mathrm{t}^{-1}\right)$, but those are higher than for the altered host rocks. All the mineralized samples contain $\mathrm{Hf}$ and Th under detection limit. The altered host rocks have a variable $\mathrm{Hf} / \mathrm{Th}$ ratio between 0.5 and 4.1. The Ti group ( $\mathrm{Zr}, \mathrm{Hf}$ and $\mathrm{Ta}$ ) is characterized by a depletion of $\mathrm{Ta}$ concentration both in mineralized vein and altered host rock. The $\mathrm{Hf}$ and $\mathrm{Zr}$ for mineralized samples is lower than altered host rock samples. The $\mathrm{Zr}$ concentration in mineralized vein in the range of $0.5-2.5 \mathrm{~g} \mathrm{t}^{-1}$, in the altered host rock samples is much higher in the range of $27.9-127.2 \mathrm{~g} \mathrm{t}^{-1}$. The compatible elements ( $\mathrm{Ni}, \mathrm{Co}, \mathrm{Cr}$ and Sc) of the mineralized vein and the altered rock are almost similar and shows low content, except for $\mathrm{Co}$ and $\mathrm{Sc}$ on altered host rock samples shows higher content. They have values of $\mathrm{Ni}$ and $\mathrm{Cr}$ similar but lower comparing the average orogenic andesite $(\mathrm{Ni}<40 ; \mathrm{Cr}$ <100; Gill, 1981).

The $\Sigma R E E$ in the mineralized vein samples are various between 1.85 to 5.01 , with the $\Sigma$ LREE/ $\Sigma$ HREE ratio are 0.98 to 6.52 . The $\Sigma$ LREE/ $\Sigma$ HREE ratio is slightly lower than Arinem vein. The Eu/Eu* ratio are between 1.1 to 6.5 and this value is almost $2 x$ of the mineralized Arinem vein samples. The ratio of the $\mathrm{Y} / \mathrm{Ho}$ also slightly higher than Arinem vein (15.0 to 43.3). The ratios of $\mathrm{Ce} / \mathrm{Ce}^{*},(\mathrm{La} / \mathrm{Yb})_{\mathrm{N}},(\mathrm{La} / \mathrm{Sm})_{\mathrm{N}}$ 
and $(\mathrm{TbYb})_{\mathrm{N}}$ are 0.7 to $1.8,0.8$ to 5.3 , 1.9 to 5.9 and 0.6 to 1.3 respectively. $\sum$ REE for altered host rock between 30.9 to $48.6 \mathrm{~g} \mathrm{t}^{-1}$ (slightly higher than Arinem vein), $\Sigma$ LREE/ $\Sigma$ HREE ratio is between 2.4 to 2.9 , ratio $\mathrm{Eu} / \mathrm{Eu}^{*}$ between 0.7 to $1.0, \mathrm{Ce} / \mathrm{Ce}^{*}$ ratio is 1.8 to 2.0 . The value of $(\mathrm{La} / \mathrm{Yb})_{\mathrm{N}}$ ratio is lower than Arinem vein (1.3 to 1.9$)$. The $(\mathrm{La} / \mathrm{Sm})_{\mathrm{N}}$ ratio is between 1.0 to $1.2,(\mathrm{TbYb})_{\mathrm{N}}$ ratio is 1.2 to 1.4 and $\mathrm{Y} / \mathrm{Ho}$ ratio is between 28.7 to 29.6. The both RREE in mineralized vein and altered host rock are depleted.
The chondritic normalized concentration of the rare-earth elements (REE) of mineralized vein and altered host rock (normalized with chondrite of Sun and McDonough, 1989) are presented in Figs. 3 and 4 . Mineralized vein ranges values are between $10^{-1}$ to $10^{1}$, and it shows random pattern probably because of very high base metal content. Altered host rock have flatted pattern and indicate slightly enrichment for LREE and constant concentration for the heavy rare-earth elements (HREE).

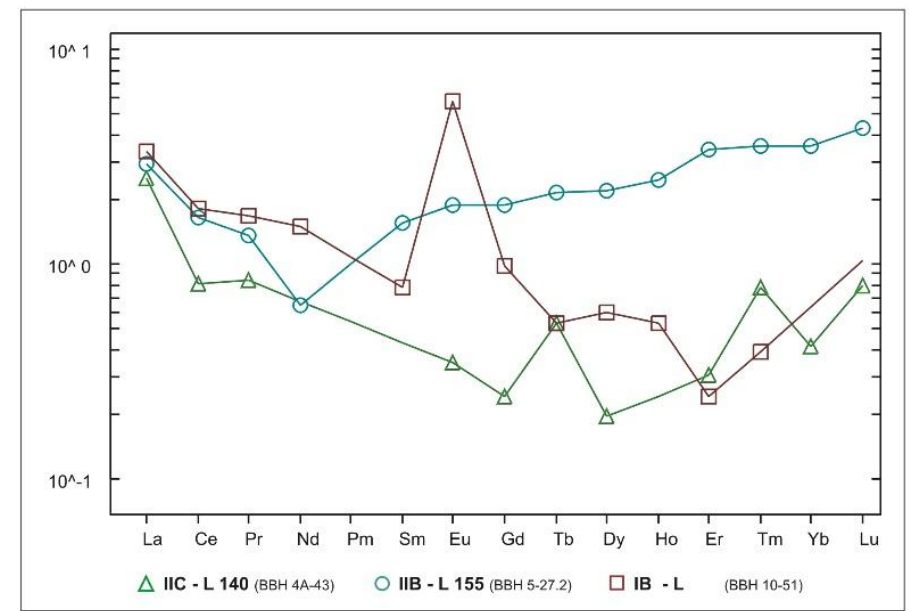

Fig. 3 Rare earth elements (REE) patterns of Bantarhuni quartz-sulfde vein.

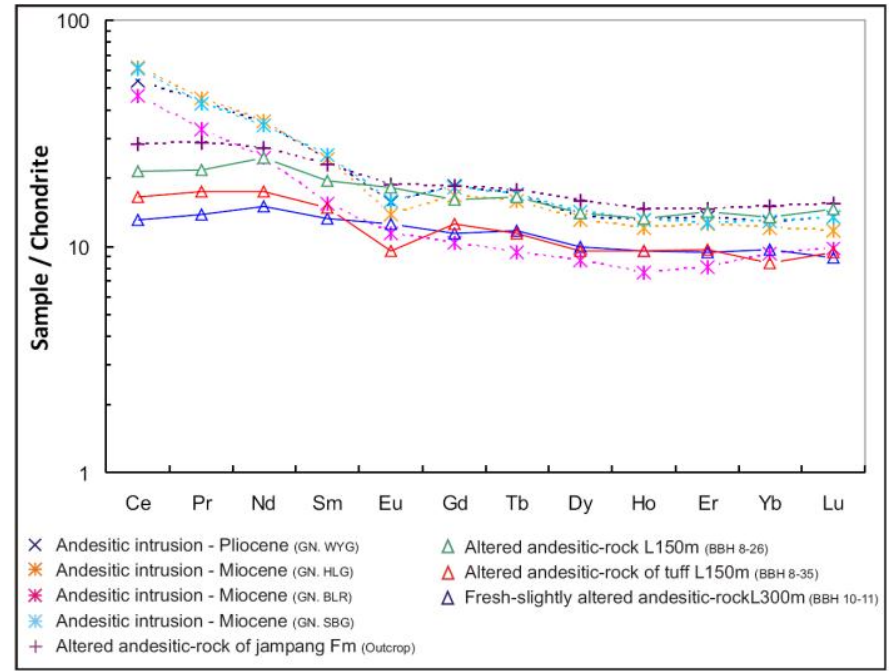

Fig. 4 Rare earth elements (REE) patterns of Bantarhuni altered host rock.

The propylitic and argillic alterations show the similar patterns. The Eu in altered volcanic host rock samples is shows slightly negative anomalous and it is suggest that all the those samples have a similar magma source. In conclusion, the Bantarhuni samples shows similar REE pattern with the
Arinem with higher $\Sigma$ REE. The LREE are relatively constant, while HREE are slightly decreased. There are also shows slight depleted in Eu and no significant anomaly in $\mathrm{Ce}$. There are relatively lower concentrations of $\Sigma$ REE in sample from Bantarhuni comparing to the Arinem veins. 


\section{Major Ore Elements Geochemistry of Bantarhuni Vein}

The analyses concluded, gold and silver grades vary from 0.4 (IIC) to $9.9 \mathrm{~g} \mathrm{t}^{-1}$ (IIC) $\mathrm{Au}$ and 22.4 (IB) to $256 \mathrm{~g} \mathrm{t}^{-1}$ (IIC) Ag. The base metal $(\mathrm{Cu}, \mathrm{Zn}$ and $\mathrm{Pb}$ ) contents vary from 0.05 (IB) to $5.9 \%$ (IIC) for $\mathrm{Cu}, 0.3$ (IIB) to $27.8 \%$ (IIC) for $\mathrm{Zn}$ and 0.1 (IIB) to $25.3 \%$ (IIC) for $\mathrm{Pb}$, respectively (Table 1 ). The content of $\mathrm{Cd}$ is 19.2 (IIB) to $1964.1 \mathrm{~g} \mathrm{t}^{-1}$ (IIC) and correlated with the highest $\mathrm{Zn}$ content. The content of $\mathrm{Bi}$ is $<0.1$ (IB) to $122.1 \mathrm{~g} \mathrm{t}^{-1}$ (IIB). Others, for $\mathrm{Se}$ is 38.0 (IB) to $>500 \mathrm{~g} \mathrm{t}^{-1}$ ((IIC) and correlated with the $\mathrm{Pb}$ content. The highest content of $\mathrm{Cd}$ is correlated with the highest content of $\mathrm{Zn}$, as well as the highest content of $\mathrm{Se}$ is found in the sample with highest content of $\mathrm{Pb}$. The content of the $\mathrm{Sb}$ is low, in the range of 2.4 to $24.3 \mathrm{~g} \mathrm{t}^{-1}$. The content of the Mo, $\mathrm{Ni}, \mathrm{As}, \mathrm{Hg}$ and $\mathrm{Tl}$ is low and some are under detection limit.

The abundance of ore and gangue minerals vary among each stage of mineralization of Bantarhuni vein. The $\mathrm{Au}, \mathrm{Ag}, \mathrm{Te}$ and base metal content in the stage $\mathrm{I}$ is $0.07 \mathrm{~g} \mathrm{t}^{-1} \mathrm{Au}, 22.4 \mathrm{~g} \mathrm{t}^{-1}$ $\mathrm{Ag}, 0.05 \% \mathrm{Cu}, 4.2 \% \mathrm{Zn}$ and $1.9 \% \mathrm{~Pb}$. The $\mathrm{Au}, \mathrm{Ag}, \mathrm{Te}$ and base metal contents in the stage II are up to $9.9 \mathrm{~g} \mathrm{t}^{-1} \mathrm{Au}$, $256 \mathrm{~g} \mathrm{t}^{-1} \mathrm{Ag}, 5.9 \% \mathrm{Cu}, 27.8 \% \mathrm{Zn}$ and $25.3 \% \mathrm{~Pb}$ (Table 1 ).

From the altered host rock, samples BBH 8-26 and BBH 8-35 of argillic zone have high content of As 143.5 and $394.8 \mathrm{~g} \mathrm{t}^{-1}$, respectively. Other elements are low, except for $\mathrm{Zn}$ (up to $382 \mathrm{~g} \mathrm{t}^{-1}$ ) and $\mathrm{Pb}$ (up to $240.3 \mathrm{~g} \mathrm{t}^{-1}$ ). The slightly high content of the $\mathrm{Zn}$ and $\mathrm{Pb}$ in the altered host rock is because of the trace of sphalerite and galena occurrences within the alteration zone. In the altered rocks Au ranges from 0.01 to $0.04 \mathrm{~g} \mathrm{t}^{-1}$, $\mathrm{Ag}$ from 0.1 to $0.3 \mathrm{~g} \mathrm{t}^{-1}$. During the alteration process a more rapid enrichment occurs for As, $\mathrm{Zn}, \mathrm{Au}, \mathrm{Ag}$, $\mathrm{Sb}, \mathrm{Pb}, \mathrm{S}, \mathrm{Se}, \mathrm{Cd}$, and $\mathrm{Hg}$. This is indicated by the analysis of the samples, particularly from the argillic alteration zone, although the increase of these elements is very variable. Most of these elements, except $\mathrm{Zn}$ and $\mathrm{Cu}$, are not detected in the fresh rocks sample. Plotting in triangular diagram do not shows meaningful correlation between content of base metal ( $\mathrm{Cu}, \mathrm{Pb}, \mathrm{Zn}$ ) with $\mathrm{Ag}$ and $\mathrm{Au}$, this probably because of limited samples analyzed (Fig. 5).

Variation diagrams for pairs of major ore elements in bulk-ore samples of Bantarhuni vein samples are given in Fig. 6 (Taylor and McLennan, 1985). The relation of some ore elements in correlation with the upper continental crust (UCC) and lower continental crust (LCC) from various authors also plotted for the Bantarhuni mineralized vein samples (Fig. 6) to understand the fractionation process of the ore elements. The $\mathrm{Zn}-\mathrm{Cd}$ and $\mathrm{Pb}-\mathrm{Zn}$ have very high correlations which conclude that there are some substitution of $\mathrm{Zn}$ by $\mathrm{Cd}$, and the abundance of sphalerite also indicated by the abundance of the galena. $\mathrm{Ag}$ and $\mathrm{Au}$ content are as indication of the presence of the electrum and petzite.

The positive correlation trends for the element groups of $\mathrm{Ag}-\mathrm{Au}-\mathrm{Te}$ and $\mathrm{Pb}-\mathrm{Se}$ $\mathrm{Zn}-\mathrm{Cd}$ point to a mineralogical control of element distribution. The $\mathrm{Ag}-\mathrm{Au}-\mathrm{Te}$ group relates to tellurium-Ag minerals, whereas the $\mathrm{Pb}-\mathrm{Se}-\mathrm{Zn}-\mathrm{Cd}$ group relates to base metal sulfides, such as galena and sphalerite. Other ore elements do not shows any correlation. The plotting of the upper continental crust (UCC) and lower continental crust (LCC) in some graphic reflect degree of the diffentiated process of the every element relative to value of the bulk continental crust composition. Several correlation trends tend toward the bulk composition of the bulk continental crust, or intersect it.

The pattern of the elemental concentration from L300m, L155m, $\mathrm{L} 140 \mathrm{~m}$ and $\mathrm{L} 140 \mathrm{~m}$ of the Bantarhuni vein vertically are plotted in Fig. 7 . The mineralized vein and altered host rock samples are plotted in the same graphic. The line bar with dashed line represented the alteration host rock samples (see Fig. 7). The plotting of the element pairs from the different elevation gives some pattern correlation of the elements. The samples limitation from the altered host rock make it is difficult to define the pattern of vertical variation in elemental concentration. The concentrations of $\mathrm{Au}$ and $\mathrm{Ag}$ are higher in deeper part comparing to the shallower part. 
Table 1 Geochemical analysis for major, minor and trace elements composition of selected quartz-sulfide and altered host rock samples of Bantarhuni vein.

\begin{tabular}{|c|c|c|c|c|c|c|c|c|c|}
\hline \multirow{4}{*}{$\begin{array}{l}\text { Substage : } \\
\text { Level } \quad \\
\text { Sample no: }\end{array}$} & \multicolumn{4}{|c|}{ Mineralized quartz vein } & \multicolumn{5}{|c|}{ Altered Host rock } \\
\hline & IB & IIB & IIC & IIC & & & & & \\
\hline & 300 & 155 & 140 & 155 & 150 & 150 & 300 & & \\
\hline & BBH $10-51$ & BBH 5-27.2 & BBH $4 \mathrm{~A}-43$ & BBH 5-28 & BBH 8-26 & BBH 8-35 & BBH 10-11 & BBH-9-5 & BBH-9-6 \\
\hline \multicolumn{10}{|l|}{ Major Elements : } \\
\hline $\mathrm{SiO}_{2}$ & 31.81 & 65.87 & 8.58 & 14.82 & 49.40 & 77.50 & 50.64 & 70.99 & 70.82 \\
\hline $\mathrm{Al}_{2} \mathrm{O}_{3}$ & 1.68 & 0.80 & 0.81 & 1.95 & 15.66 & 9.69 & 15.47 & 14.55 & 14.46 \\
\hline $\mathrm{Fe}_{2} \mathrm{O}_{3}$ & 2.31 & 19.44 & 10.31 & 22.28 & 8.22 & 4.00 & 8.57 & 4.22 & 4.30 \\
\hline $\mathrm{MgO}$ & 1.78 & 0.02 & 0.14 & 2.25 & 3.13 & 0.41 & 5.94 & 1.24 & 1.24 \\
\hline $\mathrm{CaO}$ & 33.22 & 0.04 & 0.81 & 0.11 & 6.54 & 0.25 & 5.86 & 0.31 & 0.31 \\
\hline $\mathrm{Na}_{2} \mathrm{O}$ & $<0.01$ & 0.01 & 0.01 & $<0.01$ & 0.23 & 0.07 & 0.47 & 0.32 & 0.31 \\
\hline $\mathrm{K}_{2} \mathrm{O}$ & $<0.01$ & 0.14 & 0.04 & $<0.01$ & 1.73 & 1.99 & 1.34 & 2.66 & 2.64 \\
\hline $\mathrm{TiO}_{2}$ & $<0.01$ & $<0.01$ & $<0.01$ & $<0.01$ & 0.63 & 0.61 & 0.75 & 0.56 & 0.56 \\
\hline $\mathrm{P}_{2} \mathrm{O}_{5}$ & 0.03 & 0.02 & $<0.01$ & $<0.01$ & 0.13 & 0.12 & 0.11 & 0.07 & 0.07 \\
\hline $\mathrm{MnO}$ & 1.47 & $<0.01$ & 0.11 & 0.14 & 0.74 & 0.13 & 0.55 & 0.06 & 0.06 \\
\hline LOI & 20.50 & 9.40 & 11.50 & 14.20 & 13.40 & 5.10 & 10.10 & 5.00 & 5.20 \\
\hline Sum & 92.82 & 95.70 & 32.36 & 55.69 & 99.81 & 99.83 & 99.79 & 99.94 & 99.94 \\
\hline Minor and Trace & lements : & & & & & & & & \\
\hline $\mathrm{Cr}_{2} \mathrm{O}_{3}$ & $<0.002$ & 0.005 & $<0.002$ & 0.002 & $<0.002$ & $<0.002$ & $<0.002$ & 0.004 & 0.004 \\
\hline $\mathrm{Ni}$ & $<20.00$ & 25.00 & $<20.00$ & $<20.00$ & $<20.00$ & $<20.00$ & $<20.00$ & $<20.00$ & $<20.00$ \\
\hline Sc & $<1.00$ & 39.00 & 2.00 & 1.00 & 22.00 & 17.00 & 25.00 & 16.00 & 16.00 \\
\hline $\mathrm{Ba}$ & 2.00 & 10.00 & 8.00 & 1.00 & 26.00 & 122.00 & 45.00 & 66.00 & 62.00 \\
\hline $\mathrm{Be}$ & $<1.00$ & $<1.00$ & $<1.00$ & $<1.00$ & $<1.00$ & $<1.00$ & 1.00 & $<1.00$ & $<1.00$ \\
\hline Co & 1.40 & 3.40 & 0.20 & 1.30 & 27.00 & 11.10 & 17.20 & 22.50 & 23.50 \\
\hline Cs & $<0.10$ & 0.30 & $<0.10$ & $<0.10$ & 9.70 & 3.60 & 8.00 & 11.30 & 10.90 \\
\hline Ga & 6.80 & 4.90 & 25.20 & 15.40 & 14.10 & 11.10 & 16.90 & 11.70 & 11.60 \\
\hline $\mathrm{Hf}$ & $<0.10$ & $<0.10$ & $<0.10$ & $<0.10$ & 1.60 & 1.40 & 1.20 & 1.00 & 0.90 \\
\hline $\mathrm{Nb}$ & $<0.10$ & $<0.10$ & $<0.10$ & $<0.10$ & 1.10 & 1.20 & 0.80 & 0.50 & 0.50 \\
\hline $\mathrm{Rb}$ & $<0.10$ & 3.00 & 1.20 & $<0.10$ & 71.10 & 51.70 & 42.80 & 89.20 & 88.40 \\
\hline Sn & $<1.00$ & 19.00 & $<1.00$ & 3.00 & 1.00 & 1.00 & 1.00 & 4.00 & 2.00 \\
\hline Sr & 88.60 & 3.00 & 2.50 & 0.80 & 59.30 & 17.30 & 75.30 & 25.90 & 27.00 \\
\hline Ta & $<0.10$ & $<0.10$ & $<0.10$ & $<0.10$ & $<0.10$ & $<0.10$ & $<0.10$ & $<0.10$ & $<0.10$ \\
\hline Th & $<0.20$ & $<0.20$ & $<0.20$ & $<0.20$ & 0.40 & 0.30 & $<0.20$ & 0.30 & $<0.20$ \\
\hline u & $<0.10$ & 0.30 & $<0.10$ & $<0.10$ & 0.20 & 0.20 & 0.10 & 0.10 & $<0.10$ \\
\hline v & 27.00 & 18.00 & 21.00 & 30.00 & 183.00 & 129.00 & 232.00 & 160.00 & 163.00 \\
\hline w & 192.80 & 0.60 & $<0.50$ & 0.50 & 60.10 & 306.30 & 103.00 & 41.90 & 42.80 \\
\hline $\mathrm{Zr}$ & 0.50 & 2.50 & 0.60 & 1.00 & 50.20 & 37.00 & 32.70 & 28.30 & 27.90 \\
\hline Y & 1.30 & 5.20 & 0.60 & 0.30 & 21.30 & 15.40 & 14.90 & 10.60 & 10.10 \\
\hline La & 0.80 & 0.70 & 0.60 & 0.70 & 5.20 & 3.60 & 2.90 & 1.00 & 1.00 \\
\hline $\mathrm{Ce}$ & 1.10 & 1.00 & 0.50 & 0.40 & 13.20 & 10.10 & 8.00 & 3.00 & 2.90 \\
\hline $\mathrm{Pr}$ & 0.16 & 0.13 & 0.08 & 0.03 & 2.02 & 1.62 & 1.29 & 0.45 & 0.44 \\
\hline $\mathrm{Nd}$ & 0.70 & 0.30 & $<0.30$ & $<0.30$ & 11.20 & 8.00 & 6.90 & 2.50 & 2.60 \\
\hline $\mathrm{Sm}$ & 0.12 & 0.24 & 0.05 & $<0.05$ & 2.87 & 2.18 & 1.95 & 0.91 & 0.93 \\
\hline Eu & 0.33 & 0.11 & $<0.02$ & $<0.02$ & 1.02 & 0.54 & 0.71 & 0.30 & 0.30 \\
\hline $\mathrm{Gd}$ & 0.20 & 0.39 & 0.05 & $<0.05$ & 3.20 & 2.50 & 2.28 & 1.37 & 1.37 \\
\hline $\mathrm{Tb}$ & 0.02 & 0.08 & 0.02 & $<0.01$ & 0.60 & 0.41 & 0.42 & 0.27 & 0.27 \\
\hline Dy & 0.15 & 0.56 & 0.05 & $<0.05$ & 3.43 & 2.33 & 2.43 & 1.80 & 1.74 \\
\hline Ho & 0.03 & 0.14 & $<0.02$ & $<0.02$ & 0.72 & 0.52 & 0.52 & 0.42 & 0.42 \\
\hline Er & 0.04 & 0.56 & 0.05 & $<0.03$ & 2.27 & 1.55 & 1.51 & 1.21 & 1.22 \\
\hline $\mathrm{Tm}$ & 0.01 & 0.09 & 0.02 & $<0.01$ & 0.36 & 0.24 & 0.22 & 0.18 & 0.18 \\
\hline $\mathrm{Yb}$ & 0.05 & 0.60 & 0.07 & $<0.05$ & 2.16 & 1.35 & 1.55 & 1.21 & 1.23 \\
\hline Lu & $<0.01$ & 0.11 & 0.02 & $<0.01$ & 0.36 & 0.23 & 0.22 & 0.18 & 0.19 \\
\hline ТОT/C & 7.69 & 0.12 & 0.22 & 0.03 & 2.94 & 0.44 & 1.25 & 0.02 & 0.04 \\
\hline TOT/S & 3.21 & 15.33 & 25.29 & 26.04 & 1.57 & 1.83 & 0.55 & 1.58 & 1.91 \\
\hline$\sum$ REE & 3.72 & 5.01 & 1.85 & 1.73 & 48.61 & 35.17 & 30.90 & 3.72 & 3.72 \\
\hline$\Sigma$ LREE & 3.21 & 2.48 & 1.55 & 1.50 & 35.51 & 26.04 & 21.75 & 8.16 & 8.17 \\
\hline$\sum$ HREE & 0.51 & 2.53 & 0.30 & 0.23 & 13.10 & 9.13 & 9.15 & 0.51 & 0.51 \\
\hline$\Sigma$ LREE $/ \Sigma$ HREE & 6.29 & 0.98 & 5.17 & 6.52 & 2.71 & 2.85 & 2.38 & 6.29 & 6.29 \\
\hline $\mathrm{Eu} / \mathrm{Eu}^{*}$ & 6.47 & 1.09 & . & & 1.02 & 0.70 & 1.03 & 0.82 & 0.81 \\
\hline $\mathrm{Ce} / \mathrm{Ce}^{*}$ & 1.43 & 1.76 & 1.00 & 0.71 & 1.83 & 1.99 & 1.89 & 2.00 & 1.89 \\
\hline$(\mathrm{La} / \mathrm{Yb}) \mathrm{N}$ & 5.30 & 0.84 & 6.15 & & 1.73 & 1.91 & 1.34 & 0.59 & 0.58 \\
\hline$(\mathrm{La} / \mathrm{Sm}) \mathrm{N}$ & 4.30 & 1.88 & 5.87 & & 1.17 & 1.07 & 0.96 & 0.71 & 0.69 \\
\hline$(\mathrm{Tb} / \mathrm{Yb}) \mathrm{N}$ & 0.84 & 0.61 & 1.30 & & 1.26 & 1.38 & 1.23 & 1.01 & 1.00 \\
\hline $\mathrm{Y} / \mathrm{Ho}$ & 43.33 & 37.14 & 30.00 & 15.00 & 29.58 & 29.62 & 28.65 & 25.24 & 24.05 \\
\hline Major Ore Eleme & & & & & & & & & \\
\hline Mo & 0.40 & 7.30 & 0.30 & 0.10 & 1.00 & 0.50 & $<0.10$ & 1.80 & 2.10 \\
\hline $\mathrm{Cu}$ & 488.90 & 50791.00 & 47547.00 & 59496.00 & 2.30 & 8.60 & 66.30 & 72.30 & 71.80 \\
\hline $\mathrm{Pb}$ & 19202.00 & 967.80 & 252700.00 & 217800.00 & 240.30 & 7.10 & 15.10 & 16.60 & 13.40 \\
\hline $\mathrm{Zn}$ & 41506.00 & 3010.00 & 278200.00 & 136900.00 & 164.00 & 382.00 & 128.00 & 139.00 & 141.00 \\
\hline $\mathrm{Ni}$ & $<0.10$ & 11.90 & 1.40 & 1.60 & 3.30 & 2.30 & 3.70 & 15.00 & 15.80 \\
\hline As & $<0.50$ & $<0.50$ & $<0.50$ & $<0.50$ & 143.50 & 394.80 & 8.70 & 59.00 & 63.90 \\
\hline $\mathrm{Cd}$ & 217.40 & 19.20 & 1964.10 & 1160.20 & 0.20 & 1.20 & $<0.10$ & $<0.10$ & 0.20 \\
\hline $\mathrm{sb}$ & 2.40 & 2.80 & 24.30 & 15.40 & 0.30 & 3.10 & 0.10 & 0.10 & 0.10 \\
\hline $\mathrm{Bi}$ & $<0.10$ & 122.10 & 42.90 & 6.30 & $<0.10$ & $<0.10$ & $<0.10$ & $<0.10$ & $<0.10$ \\
\hline $\mathrm{Ag}$ & 22.40 & 44.90 & 256.00 & 39.50 & 0.20 & 0.30 & 0.10 & 0.60 & 0.60 \\
\hline $\mathrm{Au}$ & 695.10 & 1931.20 & 9871.90 & 442.90 & 35.40 & 40.50 & 6.20 & 28.50 & 32.30 \\
\hline $\mathrm{Hg}$ & 0.29 & 0.06 & 3.22 & 1.44 & 0.07 & 0.25 & $<0.01$ & 0.04 & 0.04 \\
\hline $\mathrm{TI}$ & $<0.10$ & $<0.10$ & 0.10 & $<0.10$ & $<0.10$ & $<0.10$ & $<0.10$ & $<0.10$ & $<0.10$ \\
\hline $\mathrm{Se}$ & 38.00 & 212.00 & $>500.00$ & $>500.00$ & 1.60 & 2.20 & 0.50 & 1.00 & 1.30 \\
\hline $\mathrm{Te}$ & n. $a^{*}$ & n.a & n.a & n.a & n.a & n.a & n.a & $<1.00$ & $<1.00$ \\
\hline
\end{tabular}




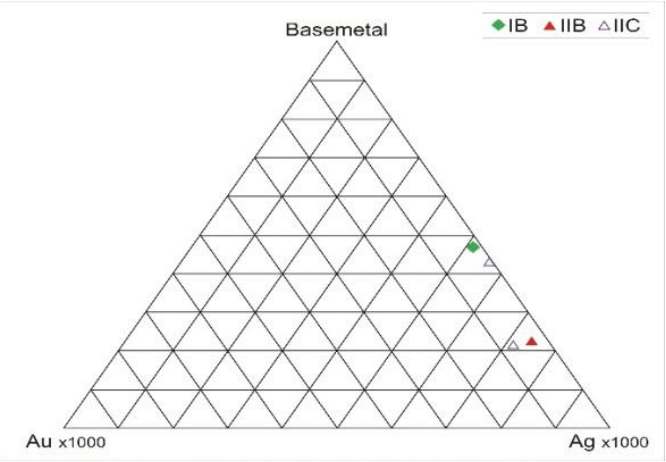

Fig. 5 Au-Ag-base metal correlation of the mineralized Bantarhuni vein.
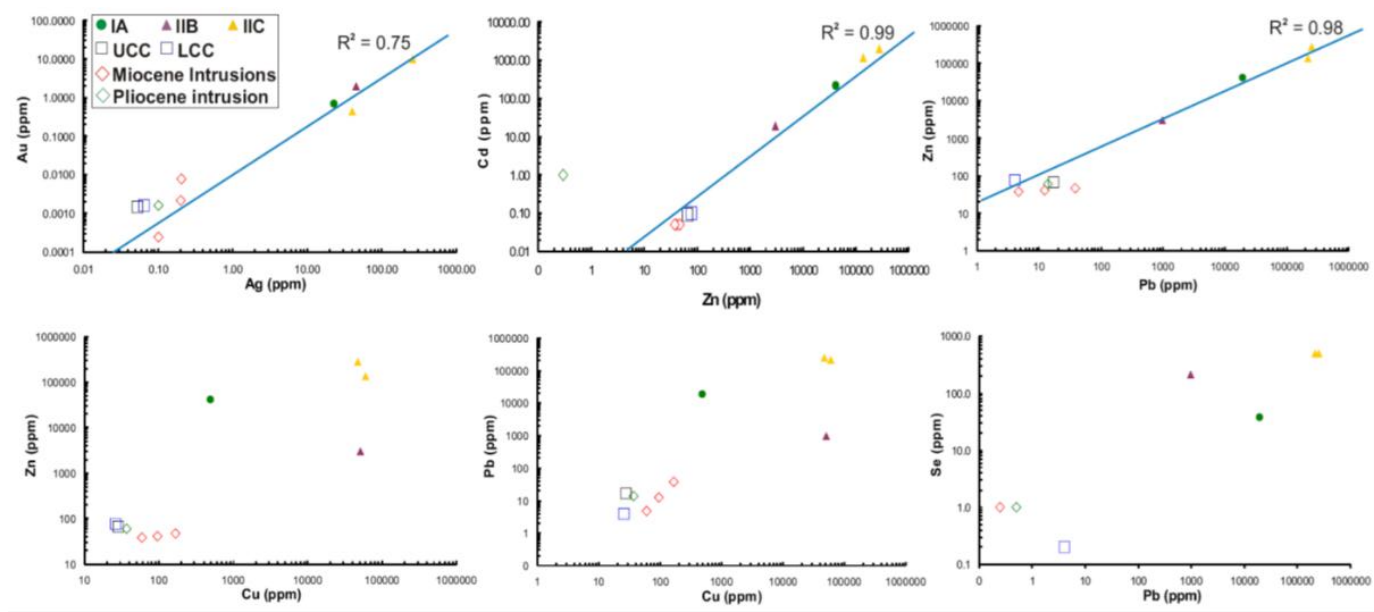

Fig. 6 Variation plots of selected trace-element pairs in bulk-ore Bantarhuni vein samples (in g t-1). Average of upper continental crust (UCC) and lower continental crust (LCC) from various author also plotted. Some diagrams show several correlation trends, which tend toward the bulk composition of the bulk continental crust (UCC \& LCC).

The increasing content of $\mathrm{Au}$ and $\mathrm{Ag}$ also accompany with the increasing of the $\mathrm{Hg}$ content. In apposite this followed by decreasing content of the $\mathrm{Mn}$. Other element such as $\mathrm{As}, \mathrm{Sb}, \mathrm{Bi}, \mathrm{Ba}$ and $\mathrm{Tl}$ have irregular patterns in correlation with the level depth. Strontium shows the highest concentration at the shallower level both for the mineralized vein and altered host rock and decrease to the deeper part.

The pattern of the $\mathrm{Au}, \mathrm{Ag}, \mathrm{Hg}$ and $\mathrm{Mn}$ in the Bantarhuni vein is similar with the pattern of the Arinem vein. Otherwise, this is not true for $\mathrm{As}, \mathrm{Sb}, \mathrm{Bi}$ and $\mathrm{TI}$ which the pattern in Bantarhuni vein is irregular. The $\mathrm{Sr}$ pattern shows the apposite correlation between the Bantarhuni and Arinem veins. The pattern of the base metal elements also show almost similar pattern with Arinem vein with some exceptional. The $\mathrm{Zn}, \mathrm{Pb}$ together with $\mathrm{Cd}$ shows higher value in deeper part and decrease approaching the shallower part, but Se shows irregular pattern, where some samples from $\mathrm{L} 155 \mathrm{~m}$ and $\mathrm{L} 140 \mathrm{~m}$ have high content of Se $\left(>500 \mathrm{~g} \mathrm{t}^{-1}\right)$. The pattern of $\mathrm{Cu}$ also show irregular pattern as shown in the Arinem vein. 


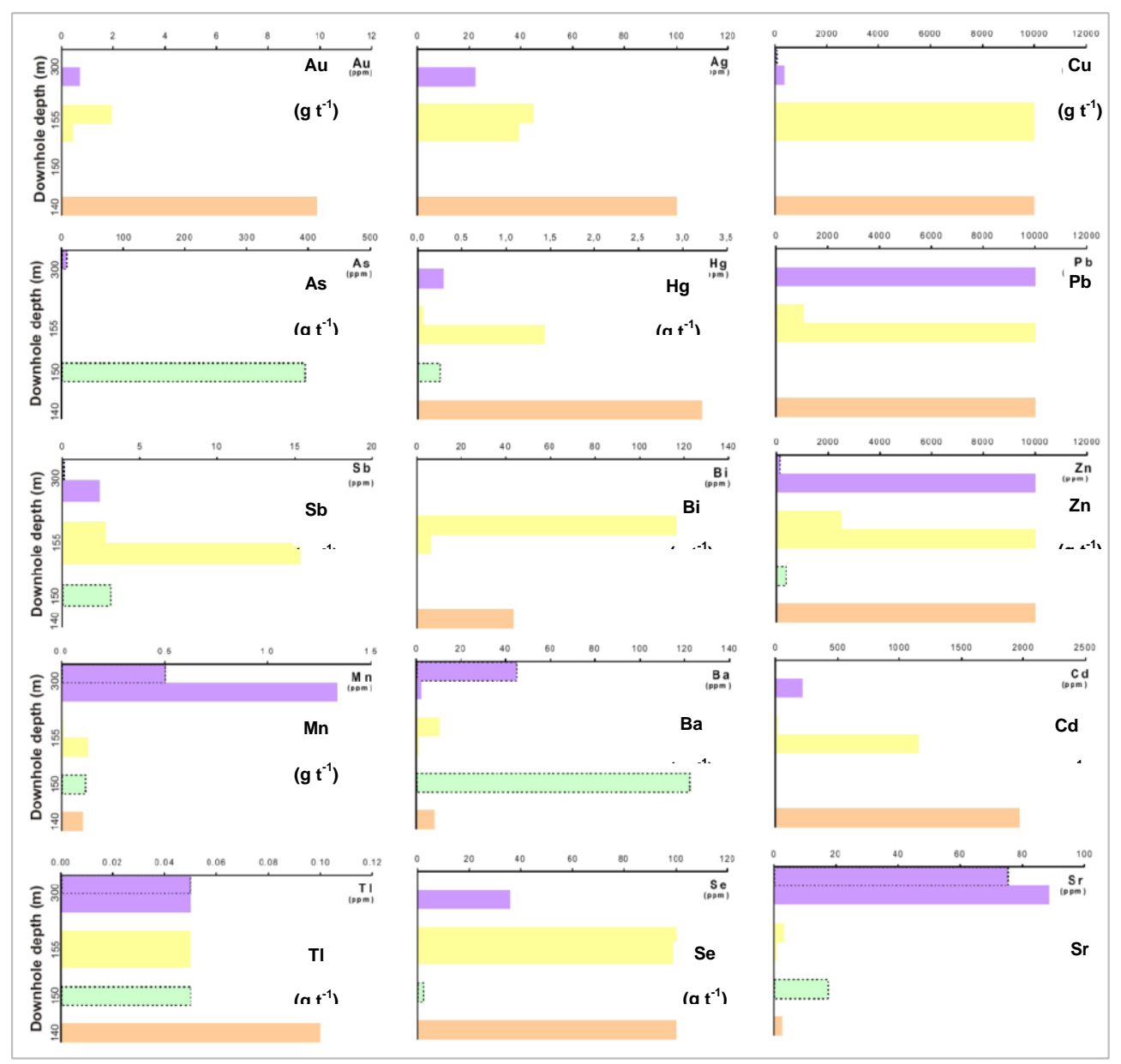

Fig. 7 Selected trace-element concentrations for mineralized quartz vein and altered host rocks from four different vertical levels in the Bantarhuni vein. Samples with dashed black line are the altered wall rocks samples.

\section{CONCLUSIONS}

The REE in the Arinem and Bantarhuni veins considered to have been extracted by water/rock interaction between hydrothermal solution and country rocks. Some REE pattern of the mineralized Bantarhuni vein show irregularly pattern and this is could be due to high content of sulfide minerals in the samples, or due to analytical error during sample dissolution. In general, the mineralized vein has lower value of the $\Sigma$ REE comparing to altered host rock, less altered Jampang Formation, and Andesitic Miocene and Pliocene intrusions samples. The lower value of $\Sigma$ REE of mineralized vein suggested lack of REE source from the hydrothermal fluids or the mobility of REE in the temperature and $\mathrm{pH}$ conditions of the ore deposition, although the carbon and oxygen isotope data suggest that there was water-rock interaction between wall rocks and fluid (meteoric water).

The trace element data for Arinem and Bantarhuni veins and altered host rock are show the samples with high $\Sigma$ REE also have the high elevated $\mathrm{Zr}$ abundances, suggestive of contamination by accessory minerals or wall-rock particles. There is a slight fractionation of the light REE (LREE) relative to the heavy REE (HREE) with $(\mathrm{La} / \mathrm{Yb})_{\mathrm{N}}$ ranges from 0.84 to 6.15 in mineralized vein and 1.03 to 5.38 in altered host rock. All samples from quartz-sulfide Arinem vein display a slight negative $\mathrm{Ce}$ anomaly and $\mathrm{a}$ positive $\mathrm{Eu}$ anomaly. The sample from stage IIB of L440m Arinem vein displays the strongest positive Eu anomalies. In apposite the pattern of REE from mineralized quartz-sulfide Bantarhuni shows random pattern. 
The gold and silver contents in the Arinem and Bantarhuni veins vary very much and there is relatively low Au and Ag concentrations occur in samples from any alteration zone. There is no correlation found between gold and other major ore elements except for $\mathrm{Ag}$. The highest content of $\mathrm{Au}$ is having low ¿REE.

The mineralization in the Arinem deposit occurs in several areas such Arinem and Bantarhuni veins. They suggest that the distribution of sulfides is related to the large of hydrothermal system. However, if these conditions cause the above variation, the systematic variation of $\mathrm{Au}$ and $\mathrm{Ag}$ with the base metals suggests that gold and silver did come from the large reservoir solution. The large distribution of the similar pattern of the precious and base metals distributions in the Arinem vein system indicate that the fluids flowed through one zone. There is evidence that the mineralized areas occur close to the plutonic bodies. In the Arinem area this zone must be in the neighbourhood of the intrusion area. By repeated fluid flow, the wall rocks and the product of early mineralization stages were repeatedly. This happened several times as shown by the presence of repeated of the gold and silver from the stage IA to stage IIC, and base metal from stage IA to stage IIIB.

\section{REFFERENCES}

Gill, J. B. (1981) Orogenic andesites and Plate Tectonics. Berlin, SpingerVerlag, 336p.

Silberman, M. L. and Berger, B. R. (1985) Relationship of traceelement patterns to alteration and morphology in epithermal precious-metal deposits. Reviews Econ. Geol., 2, p203-232.

Sun, S. S. and McDonough, W. F. (1989) Chemical and isotopic systematics of oceanic basalts: Implications for mantle composition and processes. In Saunders, A. D. and Norry, M. J., (eds.) Magmatism in the ocean basin. Geological Society of London Special Publication, 42, p313-345.

Taylor, S. R. and McLennan, S. M. (1985) The Continental Crust: Its composition and Evolution. Blackwell scientitic, Oxford, London, 312p.

Winchester, J. A. and Floyd, P. A. (1977) Geochemical discrimination of different magma series and their diffentiation products using immobile elements. Chemical Geology, 20, p325-343.

Yuningsih, E. T., Matsueda, H., Setyaraharja, E. P. and Rosana, M. F. (2012) The Arinem Te-bearing gold-silver-base metal deposit, West Java, Indonesia, Resource Geology Journal, 62, 2, p140-158.

Yuningsih, E. T. and Matsueda, $\mathrm{H}$. (2014) Genesis and origin of Tebearing gold-silver-base metal mineralization of Arinem deposit, western Java, Indonesia, Journal of Mineralogical and Petrological Science, 109, 2, p.49-61.

\section{ACKNOWLEDGEMENT}

This research project was financially supported by Ministry of Research, Technology and Higher Education of the Republic of Indonesia. 